\title{
Seasonal microphytobenthos on the hypoxic northern Gulf of Mexico continental shelf
}

\author{
Melissa M. Baustian ${ }^{1,2,3, *}$, Nancy N. Rabalais ${ }^{2}$, Wendy L. Morrison ${ }^{2}$, \\ R. Eugene Turner ${ }^{1}$
}

${ }^{1}$ Department of Oceanography and Coastal Sciences, Louisiana State University, Baton Rouge, Louisiana 70803, USA

${ }^{2}$ Louisiana Universities Marine Consortium, Chauvin, Louisiana 70344, USA

${ }^{3}$ Center for Water Sciences, Michigan State University, East Lansing, Michigan 48824, USA

\begin{abstract}
The presence of photosynthetic organisms on the seafloor may indicate whether oxygen evolution contributes to the bottom water oxygen pool in the hypoxic area of the northern Gulf of Mexico. We sampled 3 stations (depth: 14, 20 and $23 \mathrm{~m}$ ) $100 \mathrm{~km}$ west of the mouth of the Mississippi River over 3 hypoxic annual cycles to determine whether microphytobenthos or settled phytoplankton existed on the sediment surface. Microscopy and high-performance liquid chromatography were used to determine the presence and composition, and to estimate the biomass of microphytobenthos and phytoplankton in surface and bottom waters and sediments. The sediment community (cells $>3 \mu \mathrm{m}$ ) found during hypoxia differed from those in the water column and were primarily benthic (58 to $88 \%$ ). Settled pelagic phytoplankton (1 to $36 \%$ ) and tychopelagic phytoplankton (5 to $10 \%$ ) were also present. The settled phytoplankton were mostly present on the sediment during fall and winter. The abundance of benthic cells was directly correlated with light levels on the seafloor and sediment chlorophyll $a$ values. Picocyanobacteria, pennate diatoms and filamentous cyanobacteria dominated the sediment community (by density for all cells 0.2 to $8.0 \mu \mathrm{m}$ in diameter) during summer. The presence of a viable community of microphytobenthos during hypoxia indicates that the potential for photosynthetic oxygen production exists and may influence the oxygen dynamics in the hypoxic zone.
\end{abstract}

KEY WORDS: Microphytobenthos - Benthic microalgae - Cyanobacteria - Phytoplankton • Hypoxia - Northern Gulf of Mexico · Mississippi River

\section{INTRODUCTION}

Hypoxic bottom water $\left(\leq 2 \mathrm{mg} \mathrm{O}_{2} \mathrm{l}^{-1}\right)$, commonly known as the 'Dead Zone', has been detected in the northern Gulf of Mexico off the coast of Louisiana, USA, since the early 1970s (Rabalais et al. 2002) and now extends over $20000 \mathrm{~km}^{2}$ in mid-summer (Rabalais et al. 2007a). Smaller and more ephemeral hypoxic water masses are also found less frequently in mid-summer off the Texas and Mississippi coasts (Rabalais et al. 2002, 2007a), but are expanding in areal extent (N. N. Rabalais unpubl. data). Hypoxia develops from the interaction of (1) nutrient- enhanced primary production and (2) stratification resulting from freshwater discharge and thermal warming. Beginning in late winter through spring, the Mississippi and Atchafalaya rivers discharge high loads of nutrients (Rabalais \& Turner 2006) into the coastal region supporting high primary productivity of $>300 \mathrm{~g} \mathrm{C} \mathrm{m}^{-2} \mathrm{yr}^{-1}$ (Sklar \& Turner 1981, Lohrenz et al. 1990, Lehrter et al. 2009). The phytoplankton community that develops is composed of high densities of diatoms, such as Skeletonema and Chaetoceros in the spring and late summer, and of high densities of picocyanobacteria during most of the summer (Dortch et al. 2001). A high proportion of 
the primary productivity ( $\sim 50 \%)$ from spring through fall sinks to the bottom primarily as fecal pellets (which average $55 \%$ of particulate organic flux) (Qureshi 1995), diatom chains, and aggregates of diatoms and/or picocyanobacteria (Dortch et al. 2001). This high flux of organic matter increases the respiratory demand in the bottom water and sediments, and leads to oxygen depletion (Turner \& Allen 1982). The stratification between the surface and bottom water acts as a barrier to re-aeration of the bottom water, thus increasing the likelihood of hypoxic water formation.

The bottom waters have the potential to become anoxic within 4 wk or less if the organic matter supply is sufficient and bottom water temperatures are warm enough (Turner et al. 1998). If there is no mixing of the stratified layers, the time to reduce the bottom water oxygen concentration from about 6 to less than $2 \mathrm{mg} \mathrm{l}^{-1}$ (based on decline of continuous oxygen concentration data) is 18, 11 and $9 \mathrm{~d}$ in April, May and July, respectively (Rabalais et al. 2007a). Murrell \& Lehrter (2011), using below-pycnocline total respiration, estimated that $22 \mathrm{~d}$ were required for the lower water column to go from saturation to hypoxia.

Benthic photosynthesis is one process that could affect oxygen concentrations in the bottom water and could explain why severely depleted bottom water oxygen values $\left(<0.05 \mathrm{mg} \mathrm{O}_{2} \mathrm{l}^{-1}\right)$ and generation of hydrogen sulfide seldom occur, e.g. only $5 \%$ of the stations sampled from June through September between 1985 and 2005 (Rabalais et al. 2007a). Dortch et al. (1994) proposed that pelagic or tychopelagic phytoplankton species may be settling onto the sediment surface and photosynthesizing in the hypoxic region. Cahoon et al. (1990), however, found that the amount of chlorophyll (chl) $a$ in the South Atlantic Bight sediments could not be explained by settling of phytoplankton alone and proposed that microphytobenthos may be responsible for some of the benthic oxygen production.

Microphytobenthos are common to sub-tidal and shallow continental shelf sediments (Cahoon et al. 1990, Totti 2003, Cibic et al. 2007). Pennate diatoms dominated the sediments of Onslow Bay, North Carolina, and the benthic algal community differed from the planktonic algal community (Cahoon et al. 1990). Benthic diatoms were usually the most abundant, and included the genera Pleurosigma, Gyrosigma and Navicula (Totti 2003), possibly because they can photosynthesize at low light levels (Paterson 2001). Benthic cyanobacteria have also been found below diatoms in the sediments, perhaps because their phototactic gliding mobility assists in reaching light (Shilo \& Fattom 1984). Benthic cyanobacteria are also known to dominate in environments with varying $\mathrm{pH}$, redox potential (Eh), and both oxygen and hydrogen sulfide concentrations (Shilo \& Fattom 1984). In the summer, diatoms (Pleurosigma spp., Gyrosigma spp., Navicula spp.) dominate the top $1 \mathrm{~cm}$ of the sediment, but filamentous cyanobacteria (Oscillatoriales) are also present in northern Adriatic Sea sediments, a eutrophic and hypoxic area influenced by the Po River (Totti 2003). Similar microphytobenthos may be common in the northern Gulf of Mexico inner shelf sediments where eutrophication and oxygen depletion have also worsened (Rabalais et al. 2007b).

A viable microphytobenthic community has been observed on shallow, sandy shoals and nearby muddy sites off the central coast of Louisiana (Grippo et al. 2009, 2010). On Ship Shoal, a bathymetric high sand relief, the authors found relatively high sediment chl a concentrations in the spring and summer because of the presence of benthic diatoms, but few settled phytoplankton compared to the nearby muddy sites (Grippo et al. 2009). There was a higher percentage of benthic diatoms on the shoals even though the chl a concentrations did not differ among the sites (Grippo et al. 2010).

Sufficient light penetration is essential for a viable microphytobenthic community. Recent studies from the inner continental shelf of the northern Gulf of Mexico suggested that significant amounts of light reach the seafloor, but this amount varies among sites and years: Quiñones-Rivera et al. (2010) found that Secchi disk depths exceeded station depths about $30 \%$ of the time in late July 2003, but not in late July 2002, and the euphotic zone reached the seafloor on 32 to $71 \%$ of the Louisiana shelf area studied in 2005 to 2007 by Lehrter et al. (2009). The high nitrogen levels in the Mississippi River in springtime stimulate increased phytoplankton production as measured in surface waters south of Terrebonne Bay (Rabalais et al. 2007a). These spring phytoplankton blooms could potentially decrease the amount of light penetrating through the water column and inhibit benthic photosynthesis and oxygen production. Microphytobenthos in the hypoxic region of the Louisiana continental shelf may influence oxygen dynamics if sufficient light reaches the seafloor.

Our objective was to identify and quantify microphytobenthos, not just diatoms, in typical innershelf sediments in an area of frequent summer hypoxia over 3 annual cycles of hypoxia formation and persis- 
tence. Our null hypothesis was that the microalgal community composition at the sediment surface was similar to the water column (surface or bottom) due to sinking phytoplankton. Alternatively, we hypothesized that the sediment surface would have a unique community composition dominated by microphytobenthos. We also hypothesized that the deepest and least frequently hypoxic station was more likely to have a well-developed microphytobenthic community because of less shading by high biomass of phytoplankton (farther from nutrient source) and a lower likelihood of sediment resuspension.

\section{MATERIALS AND METHODS}

\section{Study area}

Three stations were studied along the $\mathrm{C}$ transect located south of Terrebonne Bay, Louisiana, an area that is usually hypoxic during summer (Fig. 1). Stns C4 ( 14 m depth, 28 57.00' N, 90³1.46' W), C6B ( $20 \mathrm{~m}$ depth, 28 $\left.52.18^{\prime} \mathrm{N}, 90^{\circ} 28.04^{\prime} \mathrm{W}\right)$ and C8 ( 23 m depth, $\left.28^{\circ} 47.30^{\prime} \mathrm{N}, 90^{\circ} 16.60^{\prime} \mathrm{W}\right)$ were sampled every 2 mo from June 2006 to July 2008, except in summer 2006 when we sampled more frequently (June, July, August).

\section{Field collection}

Several environmental parameters were measured with a multiparameter sonde (Hydrolab Surveyor 3 or YSI 6820) through the water column and as close to the seafloor as possible. A Biospherical Instruments profiling natural fluorometer (PNF-300) was used to determine the photosynthetically available radiation (PAR) at the seafloor and on the research vessel (reference PAR). The percent surface PAR reaching the seafloor was calculated by using the reference PAR (mean $\approx 1800 \mu \mathrm{mol}$ photons $\mathrm{m}^{-2} \mathrm{~s}^{-1}, \mathrm{n}=$ 36) measured from the ship at the average local times of 15:00 to $16: 00 \mathrm{~h}(\mathrm{C} 4), 13: 00$ to $14: 00 \mathrm{~h}(\mathrm{C} 6 \mathrm{~B})$, and 06:00 to 09:00 h (C8). The percent PAR calculations were used instead of the absolute PAR values to correct for differences in time of day. Attenuation coefficients using the reference PAR and bottom PAR were also calculated.

We sampled the surface water with a bucket and the bottom water with a 51 Niskin bottle (about $0.5 \mathrm{~m}$ above the seafloor). Water samples were filtered onto $47 \mathrm{~mm}$ diameter Whatman GF/F filters which were kept in liquid nitrogen until further processing for phytopigment analyses. Surface and bottom water samples for microscopic analyses were preserved in Nalgene bottles containing $1 \mathrm{ml}$ glutaraldehyde (50\%) and filled to $100 \mathrm{ml}$ with filtered sea water. Bottom water samples were analyzed for nitrate+ nitrite, ammonium, silicate and phosphate on a Lachat auto-analyzer II system (8000 series) with an autosampler (ASX-400 series) according to United States Environmental Protection Agency methodology (Methods 353.2, 350.1 and 365.2 in USEPA 1983).

We collected sediment at each station from 5 intact GOMEX box cores $(0.5 \mathrm{~m}$ high, $0.3 \mathrm{~m}$ long, $0.3 \mathrm{~m}$ wide, surface area $0.09 \mathrm{~m}^{2}$ ). An 'intact' box core retained overlying water and the sediment surface was visibly undisturbed. Stn C8 was more challenging to sample than the other stations due to the sandy nature of the sediment and occasionally little overlying water remained. Subsamples were taken using 2 acrylic core tubes $(7.6 \mathrm{~cm}$ diameter) from the middle

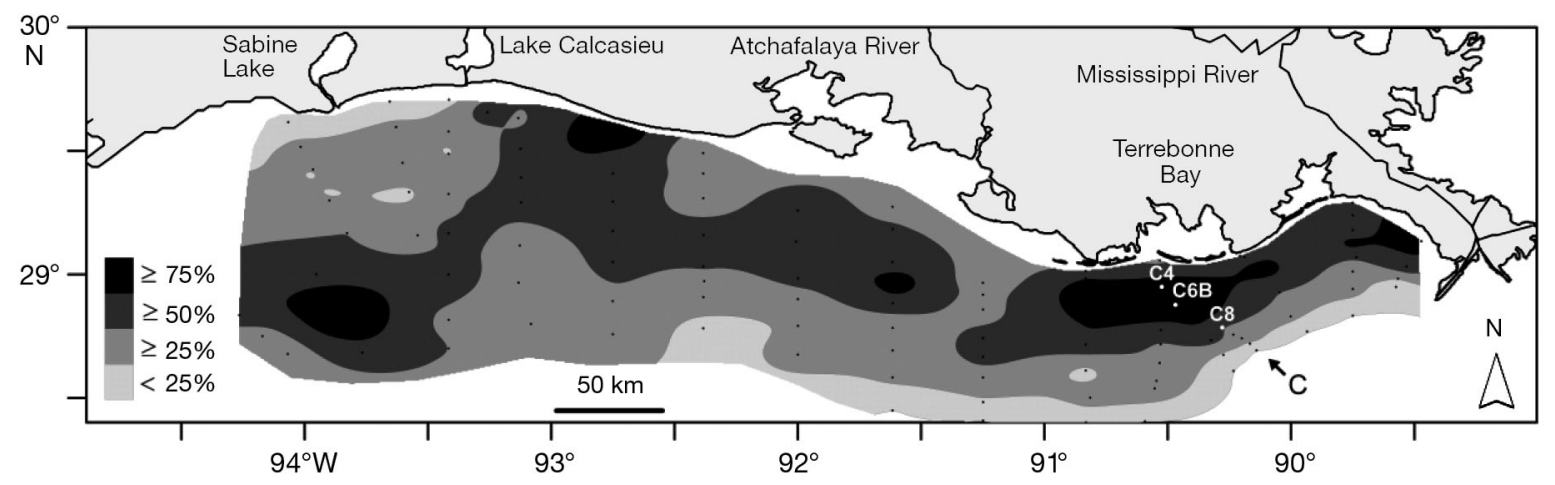

Fig. 1. Frequency of mid-summer bottom water hypoxia $\left(\leq 2 \mathrm{mg} \mathrm{O}_{2} \mathrm{l}^{-1}\right)$ off the coast of Louisiana and Texas for 60 to 80 stations (small dots) sampled during the summer from 1985 to 2008. Stns C4, C6B and C8 are labeled on the C transect. The frequency distribution is updated and modified from Rabalais et al. (2002, 2007a) 
of the box cores to avoid potentially disturbed edges. After the water was carefully removed from the sediment surface by pipette, the top $0.5 \mathrm{~cm}$ was removed from each subcore with a precision core extruder (Fuller \& Butman 1988), because light usually penetrates only the top millimeters of the sediment (MacIntyre et al. 1996). The sediment was homogenized in a Petri dish and used to fill 2 cryovials $(1.8 \mathrm{ml}$ each, stored in liquid nitrogen) for pigment analysis and 2 cryovials $\left(1.25 \mathrm{ml}\right.$ each, stored at $\left.4^{\circ} \mathrm{C}\right)$ for total organic carbon (TOC) analysis. As we expected variability within box cores and among box cores, 5 replicates were analyzed for sediment pigments and 3 for sediment TOC. The rest of the sediment $(\sim 17 \mathrm{ml}$ of slurry) from the first subcore was preserved for microscopy in a $125 \mathrm{ml}$ Nalgene bottle with $1 \mathrm{ml}$ of glutaraldehyde $(50 \%)$ and filtered sea water to make a total of $100 \mathrm{ml}$. Only 1 sample per station was taken for microscopic analysis. The second subcore from each box core was sampled for grain size analysis, but only 3 of the 5 replicates were analyzed.

\section{Laboratory analyses}

Pigments were extracted in a dark room by sonication in cold high-performance liquid chromatography (HPLC)-grade $100 \%$ methanol for water samples and sonication with cold HPLC-grade $100 \%$ acetone for sediment samples. The filtered $(0.2 \mu \mathrm{m})$ extract was injected into a Waters ${ }^{\circledR}$ HPLC system equipped with a 600 controller, 600 pump, 996 photodiode array detector and 474 fluorescence detector based on the methods of Wright et al. (1991). The water content of the sediment samples was minimized by pipetting water from the core sediment surface before extruding and was considered to have a minimal effect on concentration. We found high levels of pigment degradation products in the sediment and therefore used 3 columns (Waters ${ }^{\circledR}$ Nova-pak ${ }^{\circledR} \mathrm{C}_{18}$ $3.9 \times 150 \mathrm{~mm}$, a Rainin Microsorb ${ }^{\mathrm{TM}} \mathrm{C}_{18}$ and a Vydac $^{\circledR}$ Reverse-Phase $C_{18}$ ) to separate and identify pigments. Sediment samples were run for $75 \mathrm{~min}$ with a gradient elution of 80:20 methanol:ammonium acetate, 90:10 acetonitrile:water, and 100\% ethyl acetate. Only 1 column (Waters ${ }^{\circledR}$ Nova-pak ${ }^{\circledR} \mathrm{C}_{18} 3.9$ $\times 150 \mathrm{~mm}$ ) was needed for phytopigment analysis of the water samples, and the samples were run for 30 min on the same gradient elution. We used retention times and visible absorption spectra from DHI LAB standards as well as data and graphic sheets from Jeffrey et al. (1997) to help identify the pigments present. Some phytopigments were left out of the water and sediment analysis because the concentrations were zero or minimal for the majority of the samples. These included: neoxanthin, lutein, myxoxanthophyll, canthaxanthin, echinenone and prasinoxanthin.

The sediment percent TOC by weight was determined with a Perkin Elmer CHN Model 2400 elemental analyzer after drying and grinding the sediment and acidifying to remove calcium carbonates (Hedges \& Stern 1984). To determine sediment grain size by weight, we removed organics with $6 \%$ hydrogen peroxide, dispersed the sediments in hexametaphosphate and wet sieved $(63 \mu \mathrm{m})$ to separate the sand from the mud.

\section{Microscopy}

Since pigment data do not differentiate between water column phytoplankton and microphytobenthos, we used epifluorescence microscopy to determine the community composition of surface and bottom water and sediment samples (adapted from Dortch 1998). The water samples were size fractionated by filtering onto $0.2,3.0$ and $8.0 \mu \mathrm{m}$ polycarbonate filters. The 3.0 and $8.0 \mu \mathrm{m}$ filters were stained with $0.03 \%$ proflavine to highlight the nuclei and chloroplasts. No stain was used on the $0.2 \mu \mathrm{m}$ fraction to facilitate the identification of the natural pigments phycoerythrin $\left(\mathrm{PE} ; \mathrm{PE} /\right.$ low phycourobilin $=\mathrm{PE}-\mathrm{Pub}_{\text {low }}$ and $\mathrm{PE} /$ high phycourobilin $=$ PE-Pub ${ }_{\text {high }}$ ) and phycocyanin (PC). All size fractions were counted on an Olympus BH-2-RFCA epifluorescence microscope with blue and green excitation. The 0.2 and $3.0 \mu \mathrm{m}$ fractions were counted within $1 \mathrm{wk}$ of filtration at $1000 \times$ magnification. The $8.0 \mu \mathrm{m}$ filter was frozen to be count later at $200 \times$ magnification with epifluorescence and also transmitted light to help with identification. Each filter was counted until either 100 cells or 100 views were reached. Identification of all cells was taken to the lowest level possible. Cell counts were converted to number per liter.

The sediment samples were resuspended, and $0.5 \mathrm{ml}$ of the sediment slurry was removed, rinsed with distilled and deionized water and centrifuged to remove picocyanobacteria and other small cells that were decanted onto 0.2 and $3 \mu \mathrm{m}$ filters. A separate sediment slurry (2 to $4 \mathrm{ml}$ ) sample was needed to extract the larger cells. Ludox ${ }^{\circledR}$ HS-40 was added to the pellet to separate the larger cells from the sediment by density centrifugation (Blanchard et al. 1988, Totti 2003). Proflavin (0.03\%) vital stain was added prior to filtration onto an $8 \mu \mathrm{m}$ filter. The same 
counting and identification methodology employed for the water samples was used for the sediment samples to ensure data compatibility. Cell counts were converted to cells per $\mathrm{g}$ of dry sediment (cells $\mathrm{g}$ dry $\left.\operatorname{sed}^{-1}\right)$.

Niches were assigned to each microalgal taxon as suggested by Round et al. (1990), Tomas (1997), and Komárek et al. (2003). The pelagic niche was assigned to organisms living in the water column, tychopelagic to cells that adapt to both the water and sediment and benthic to cells associated with the sediment (Cahoon et al. 1994). We characterized the community using niches instead of shape of the cells, such as centric versus pennate, because of the presence of filamentous cyanobacteria and to avoid confusion with the centric diatoms that live in the sediments and the pennate diatoms that live in the water. Missing samples for microscopic identification include: June 2006 surface and bottom water (C4, C6B, C8) and July 2006 sediment surface.

\section{Statistical analyses}

A community composition analysis was performed using the software Plymouth Routines in Multivariate Ecological Research (PRIMER) version 6.0. The monthly data were standardized to percents (of total density) to develop the Bray-Curtis similarity index and analyzed by developing a non-parametric multidimensional scaling (MDS) plot to determine if the phytoplankton and microphytobenthic composition of the sample types - surface water (SW), bottom water (BW) and sediment surface (SS) - were similar at each station. MDS plots help visualize composition similarity by utilizing distance relationships: the closer the points are to each other, the more similar are the data. These plots also provide stress values to suggest how well the MDS configuration fits the data. Since the MDS plots do not report quantified group differences, we used analysis of similarity (ANOSIM) with 999 permutations (random re-sampling of data) to help determine if the sample types (i.e. SW, BW, SS) from the monthly compositions for each station were significantly different. These tests help to determine if the sediment surface is different from the water column.

We also used the exploratory analysis SIMPER (similarity percentages) to determine the total average dissimilarity between sample types and the percent contribution of the top taxa contributing to the separation based on a Bray-Curtis similarity index of the percent data. The SIMPER test determines which taxa groups are responsible for the differences in sample types (i.e. SW, BW, SS) and thus provides useful ecological information on why they may differ. A seasonal analysis was conducted by grouping the months into 4 seasons of 3 consecutive months beginning in January. Our null hypothesis for all tests was that there was no difference among sample types, stations or seasons when $\alpha=0.05$. To test for significant differences among stations, an analysis of variance (ANOVA) was performed on the natural logtransformed pigment and density data to meet assumptions of normality when using the PROC MIXED statement in SAS 9.1. If significance was detected, a post-hoc Tukey-Kramer test allowed for pairwise comparisons. To determine correlations among environmental variables and samples, a correlation biplot based on principal component analysis (PCA) was developed using the correlation matrix on standardized data and an $\alpha$ decomposition of 0.5 for a symmetrical plot with the PROC PRINCOMP statement and biplot macro in SAS 9.1. Plots were created and analyzed in SigmaPlot version 10.

\section{RESULTS}

\section{Phytopigment composition - chlorophylls and derivatives}

The concentration of chl a (an indicator for biomass of photosynthetic organisms) in sediments was variable, but generally less than $2 \mu \mathrm{g} g$ dry $\operatorname{sed}^{-1}$ at all stations except at Stn C8 in summer 2006 when the chl a levels were high ( 4 $\mu \mathrm{g} g$ dry sed ${ }^{-1}$; Fig. 2$)$. The mean sediment chl a concentrations at Stns C4 ( $\mathrm{n}=$ $70)$, C6B $(n=69)$ and C8 $(n=70)$ were $0.67,0.36$ and $0.99 \mu \mathrm{g} g$ dry $\operatorname{sed}^{-1}$, respectively. The concentration of chl $a$ at Stn C6B was significantly lower than at Stns C8 $\left(t_{206}=-3.74, \mathrm{p}=0.0007\right)$ and C4 $\left(t_{206}=2.76\right.$, $\mathrm{p}=0.0174$ ). The concentration of chl $a$ at Stn C4 was, in general, highest in the summer (i.e. August 2006, September 2007, July 2008) and lowest in spring for most years. Similarly, the concentration of chl a at Stn C6B was higher in the late summer, fall and winter (i.e. August 2006, September 2007 to January 2008). The sediment chl a concentration at Stn C8 was highest (about $4 \times$ higher compared to the rest of the samples) in summer 2006, low (1.5 $\left.\mu \mathrm{g} \mathrm{g} \mathrm{dry} \mathrm{sed}{ }^{-1}\right)$ in fall 2006 and winter 2007, and lowest (1 $\mu \mathrm{g} g$ dry $\mathrm{sed}^{-1}$ ) in spring and summer 2008. There was no obvious relationship between the high levels of chl a in the water column and the high levels of chl $a$ in the sediment surface for all stations (Fig. 2). 

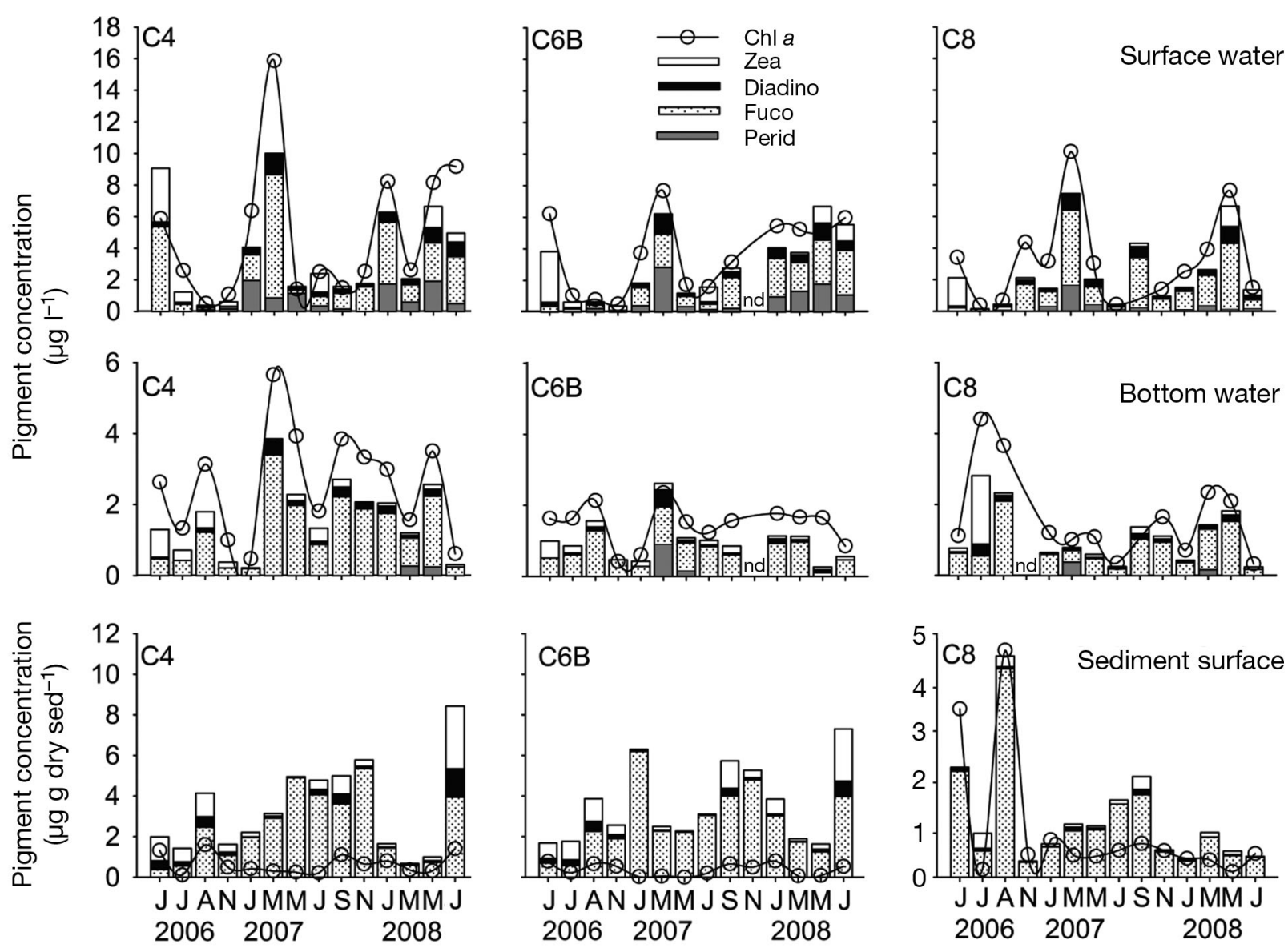

Fig. 2. Phytopigment concentrations in the surface water, bottom water and sediment surface from June 2006 to July 2008 at Stns C4, C6B and C8 (see Fig. 1). The carotenoids are represented in the stacked bars (Zea = zeaxanthin, Diadino = diadinoxanthin, Fuco = fucoxanthin, Perid = peridinin) and chlorophyll (chl) $a$ is the line. nd = no data. The month abbreviations start with June, July, August and November in 2006 and with January in 2007; remaining samples were taken every 2 mo. Note the different $y$-axes. Identifiable, but low, concentrations of other pigments were not graphed, including alloxanthin, $\beta$-carotene, diatoxanthin, violaxanthin, and 19'-hexanoyloxyfucoxanthin

The concentration of pheophytin a and pyropheophytin a (degradation products of chl a) in surface sediments, tended to be as high, or higher, than the concentration of chl a (data not shown). The concentration of degradation products was less than $2.5 \mu \mathrm{g} \mathrm{g}$ dry sed ${ }^{-1}$ at all stations. The concentration of pheophytin $a$ at Stn $\mathrm{C} 4$ was greater than the concentration of chl $a$ in March and November 2007 and July 2008, whereas peaks of pheophytin a occurred at Stn C6B in winter 2007 and summer 2008. The sediment surface at Stn C8 had the lowest values of the chl a derivatives except in July 2006, and the concentrations of chl a were greater than pheophytin $a$. Pyropheophytin a concentrations were usually less than pheophytin a concentrations in the sediment surface at all stations. The concentration of pheophytin a was also lower $(\sim 3 \times)$ than chl $a$, and no pyropheophytin a was present in the surface and bottom water samples.

\section{Phytopigment composition-carotenoids}

The sediment surface phytopigment composition was dominated by fucoxanthin during most months at all stations (Fig. 2). The mean concentration of fucoxanthin was $2.42 \mu \mathrm{g} \mathrm{g}$ dry sed ${ }^{-1}$ at $\mathrm{C} 4(\mathrm{n}=70), 2.71$ $\mu \mathrm{g} \mathrm{g}$ dry sed ${ }^{-1}$ at C6B $(\mathrm{n}=69)$ and $1.14 \mu \mathrm{g} \mathrm{g}$ dry sed ${ }^{-1}$ at C8 $(\mathrm{n}=70)$. The concentration of fucoxanthin was significantly less at C8 compared to Stns C4 $\left(t_{206}=\right.$ $5.03, \mathrm{p}=0.0001)$ and $\mathrm{C} 6 \mathrm{~B}\left(t_{206}=5.83, \mathrm{p}=0.0001\right)$. The concentration of fucoxanthin followed a general seasonal pattern of higher concentrations in the summer and fall and was lower in the spring (Fig. 2). 
Other common pigments present on the sediment surface were zeaxanthin, diadinoxanthin and 19'hexanoyloxyfucoxanthin (not shown), which tended to make up the rest of the sediment pigment pool at all stations (Fig. 2). Stns C4 and C6B had the highest combined carotenoid levels. The concentration of zeaxanthin followed a seasonal pattern with increasing concentrations in the summer and fall months compared to the rest of the year at all stations.

The surface water and bottom water tended to have more pigments with higher concentrations present (Fig. 2) than the sediment surface and included additional pigments, such as peridinin and $\beta$-carotene (not shown), that were not commonly found on the sediment surface. The surface water and bottom water were similar to the sediment surface in having high concentrations of fucoxanthin during most months.

\section{Community composition}

The sediment surface community composition (at all levels of size fractions) differed from the surface and bottom water at all 3 stations, based on the different taxonomic composition that produced separation among the sample types in the MDS plots (plots not shown, but statistics reported in Table 1). Stress values of $\sim 0.10$ from the MDS plots indicate that the goodness-of-fit was reasonable. Some of the R values from the ANOSIM analysis were low $(\sim 0.25)$, but statistically significant, suggesting differences among sample types, although overlap was identified in the MDS plot. The only null hypothesis not rejected, with regard to similarity, was between surface and bottom water at Stn C8 ( R = $0.04, p=0.143)$. The sediment surface community (all size fractions) composition varied seasonally only at Stn C4, with spring versus winter and summer versus winter being significantly different $(\mathrm{C} 4$ global $\mathrm{R}=0.33, \mathrm{p}=0.015$, spring vs. winter $\mathrm{R}=0.57, \mathrm{p}=0.029$, summer vs. winter $\mathrm{R}=0.46, \mathrm{p}=0.016$; C6B global $\mathrm{R}=0.19, \mathrm{p}=0.124 ; \mathrm{C} 8$ global $\mathrm{R}=0.27, \mathrm{p}=0.065)$.

Picocyanobacteria (cell size 0.2 to $3 \mu \mathrm{m})$ dominated the community composition in all sample types and at all stations, and were higher (percentages) in sediments than in surface and bottom waters (data not shown). The picocyanobacteria contributed a mean of $99 \%$ and varied between 97.5 and $99.9 \%$ of the total sediment community cell density at all stations. The seasonal picocyanobacteria density peaks were evident in spring and summer when they were about 7 times greater than the mean densities (not including peaks). The mean sediment picocyanobacteria densities differed among the stations $\left(\mathrm{C} 4=1.4 \times 10^{7}, \mathrm{C} 6 \mathrm{~B}=1.7 \times 10^{7}, \mathrm{C} 8=4.3\right.$ $\times 10^{6} ; \quad F_{2,38}=3.78, \mathrm{p}=0.0319, \mathrm{n}=41$ ) with densities at Stn C8 significantly lower than Stn C6B $\left(t_{38}=2.73, p=0.0254\right)$. The combined surface and bottom water mean percentage of total picocyanobacteria cells contributing to the community was $85 \%$ (range = 15 to $99 \%$ ). The highest densities of picocyanobacteria in surface and bottom waters at all stations usually occurred during the summer months of July to September.
Table 1. Comparison of microalgal community composition by size fractions between sample types (Sa. ty.), sediment surface (SS) versus surface water (SW) and SS versus bottom water (BW) at Stns C4, C6B and C8 (see Fig. 1). The multidimensional (3D) scaling plot stress value indicates the goodness-offit for the SW, BW, and SS data. ANOSIM results indicate differences between the sample types (e.g. SS vs. SW). SIMPER was used to analyze the total average dissimilarity (Diss.) between the sample types and the percent contribution (Con. \%) of the top taxa contributing to the separation (Diss.). Bold: SS average taxa abundance was greater than the SW or BW average taxa abun-

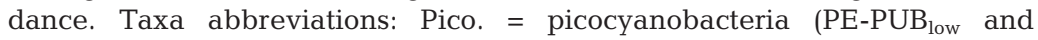
PE-PUB $\left.{ }_{\text {high }}\right)$, F.Cy. = filamentous cyanobacteria, P.-n. = Pseudo-nitzschia spp., and C.Di. = centric diatoms $(<10 \mu \mathrm{m})$

\begin{tabular}{|lccccccccc}
\hline \multirow{2}{*}{ Size $(\mu \mathrm{m})$ ) } & Sa. ty. & Stn & \multirow{2}{*}{ Stress } & \multicolumn{2}{c}{ ANOSIM } & \multicolumn{3}{c}{ SIMPER } \\
& & & & R & p & Diss. & Taxa & Con. $(\%)$ \\
\hline $0.2,3,8$ & & SW & C4 & 0.09 & 0.53 & 0.001 & 70.8 & Pico. & $\mathbf{3 1 . 1}$ \\
& SW & C6B & 0.07 & 0.42 & 0.001 & 64.5 & Pico. & $\mathbf{3 2 . 5}$ \\
& SW & C8 & 0.10 & 0.28 & 0.001 & 53.4 & Pico. & $\mathbf{3 1 . 9}$ \\
& BW & C4 & & 0.71 & 0.001 & 58.4 & Pico. & $\mathbf{3 3 . 8}$ \\
& BW & C6B & & 0.25 & 0.002 & 53.0 & Pico. & $\mathbf{3 3 . 2}$ \\
& BW & C8 & & 0.30 & 0.001 & 48.2 & Pico. & $\mathbf{3 1 . 6}$ \\
& SW & C4 8 & 0.09 & 0.55 & 0.001 & 76.7 & Pico. & $\mathbf{3 5 . 1}$ \\
& SW & C6B & 0.08 & 0.51 & 0.001 & 72.6 & Pico. & $\mathbf{3 4 . 7}$ \\
& SW & C8 & 0.09 & 0.60 & 0.001 & 80.9 & Pico. & $\mathbf{4 0 . 8}$ \\
& BW & C4 & & 0.18 & 0.002 & 51.1 & Pico. & $\mathbf{3 4 . 3}$ \\
& BW & C6B & & 0.12 & 0.024 & 34.3 & Pico. & 34.9 \\
& BW & C8 & & 0.18 & 0.003 & 41.0 & Pico. & $\mathbf{3 5 . 2}$ \\
& SW & C4 & 0.13 & 0.76 & 0.001 & 93.4 & F.Cy. & $\mathbf{7 . 5}$ \\
& SW & C6B & 0.15 & 0.83 & 0.001 & 94.8 & F.Cy. & $\mathbf{8 . 7}$ \\
& SW & C8 & 0.17 & 0.75 & 0.001 & 94.2 & P.-n. & 5.8 \\
& BW & C4 & & 0.62 & 0.001 & 90.2 & F.Cy. & $\mathbf{8 . 1}$ \\
& BW & C6B & & 0.56 & 0.001 & 88.3 & F.Cy. & $\mathbf{9 . 2}$ \\
& BW & C8 & & 0.45 & 0.001 & 91.8 & C.Di. & 4.3 \\
& & & & & & & & & \\
\hline
\end{tabular}


By analyzing the combined size fractions $(0.2,3$ and $8 \mu \mathrm{m}$ ), we found that the density of picocyanobacteria contributed the most and dominated the dissimilarity of the community composition between the sample types (SS vs. SW and SS vs. BW) for all stations (Table 1). The Bray-Curtis average dissimilarity for all size fractions $(0.2,3$ and $8 \mu \mathrm{m})$ among the sample types ranged between 53 and 70 for all stations. An average dissimilarity value of 100 indicates complete difference, while a zero represents no difference. Thus, these values suggest that the communities differed. The high densities of sediment picocyanobacteria (with PE-PUB Low + PE-PUB $_{\text {High }}$ ) present on the 3 and $8 \mu \mathrm{m}$ filters, as seen by the top taxa in Table 1, produced the separation between the sediment and water column communities at all stations. Eliminating the picocyanobacteria from the $8 \mu \mathrm{m}$ fraction analysis caused the average dissimilar- ity in most cases, to increase from 50-70 to 90 for all stations. This pattern was evident with the $\mathrm{R}$ values from the ANOSIM as well, indicating that the community composition differed more among the larger than the smaller cell sizes (Table 1). In addition, the top taxon in the $8 \mu \mathrm{m}$ fraction contributed more evenly (i.e. $\sim 10 \%$ ) to the community composition difference, while in the smaller fractions $(0.2$ and $3.0 \mu \mathrm{m})$ we found the top taxon made up a larger proportion of the contribution (i.e. $~ 30 \%$ ).

We omitted the data on picocyanobacteria density from further analysis so that the majority of the larger cells could be examined in greater detail. Diatoms represented the majority of the larger cells in the sediment surface community at all stations and for most of the time (Fig. 3). Compared to the water column, the sediment surface was less diverse in taxa and contained fewer cryptomonads, phytoflagellates

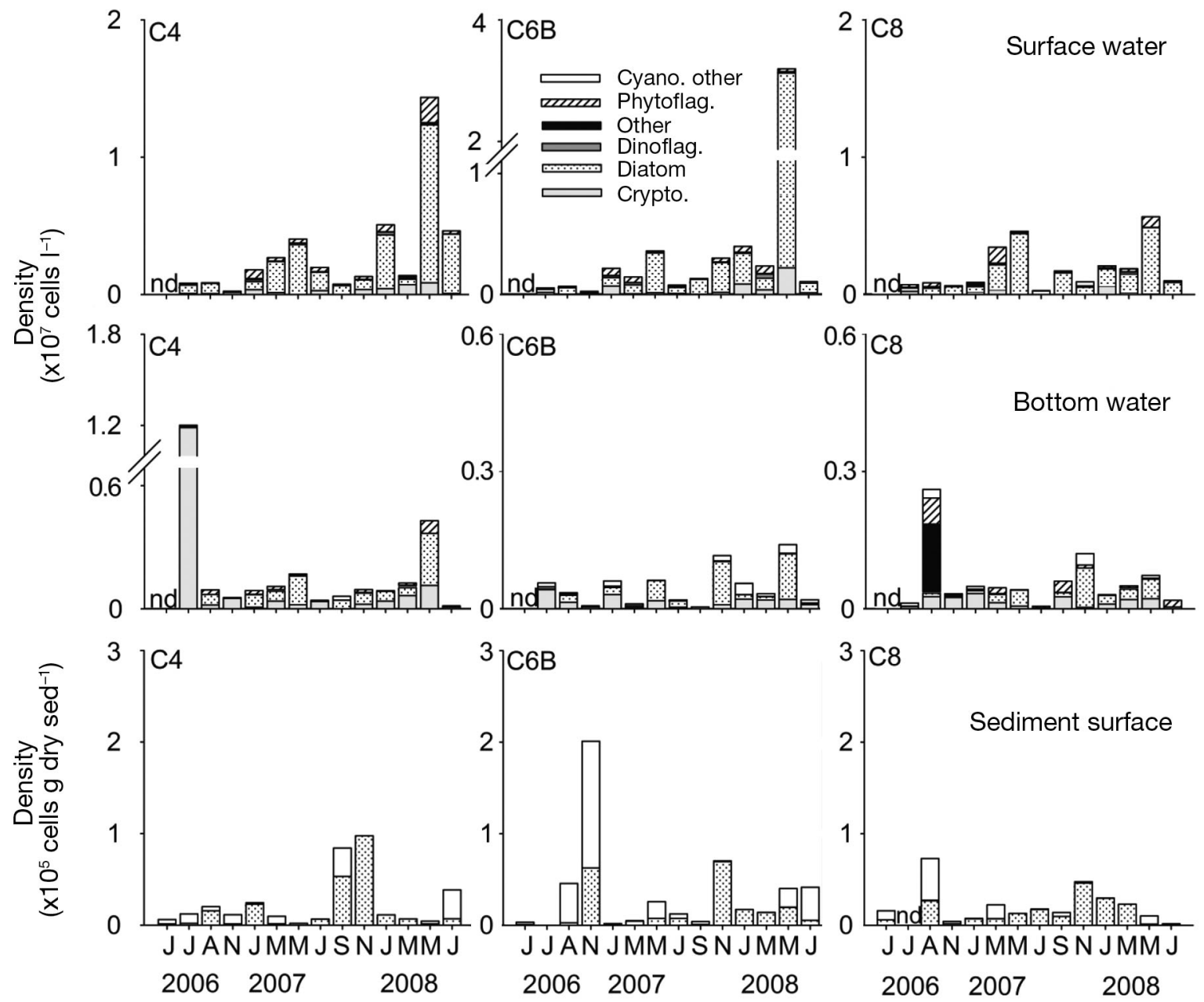

Fig. 3. Density of microalgae by taxonomic group: cyanobacteria-other (no picocyanobacteria), phytoflagellates, other (chlorophytes, ciliates, euglenoids, silicoflagellates, ebriids and raphidiophytes), dinoflagellates, diatoms, and cryptomonads for Stns C4, C6B and C8 (see Fig. 1) sampled from surface water, bottom water and sediment surface from June 2006 to July 2008. nd = no data. Month abbreviations as in Fig. 2. Note the different $y$-axis ranges 
and dinoflagellates. The highest density $\left(9.8 \times 10^{4}\right.$ cells $\mathrm{g}$ dry sed ${ }^{-1}$ ) of diatoms (Skeletonema tropicum, $S$. costatum and pennate diatoms $>3.0 \mu \mathrm{m}$ ) present on the sediment surface occurred at Stn $\mathrm{C} 4$ in November 2007. Stn C6B also had peaks of diatom density in November of 2006 and 2007 (6.2 and $7.0 \times$ $10^{4}$ cells g dry sed ${ }^{-1}$, respectively), with the common organisms being Pleurosigma spp. ( 30000 cells $g$ dry sed $\left.{ }^{-1}\right)$, Nitzschia spp., Navicula spp. and centric diatoms (20 to $30 \mu \mathrm{m}$ diameter) in 2006 and $S$. tropicum, S. costatum and centric diatoms (10 to $20 \mu \mathrm{m}$ diameter) in 2007. The mean diatom densities among the stations were not significantly different $\left(F_{2,38}=\right.$ 0.37, $\mathrm{p}=0.6961$ ). Stn C8 did not have the peaks in diatom density that were seen at the other 2 stations, but had higher median monthly densities (C8 median $=9698, \mathrm{n}=13 ; \mathrm{C} 6 \mathrm{~B}$ median $=6412, \mathrm{n}=14 ; \mathrm{C} 4$ median $=6629, \mathrm{n}=14$ ). The most common diatoms (based on high density per month) present on the sediment surface at Stn C8 were benthic pennates of the genera Amphora, Lyrella or Fallacia, Navicula and Pleurosigma. The common pelagic taxa found on the sediment surface at C8 were Asterionellopsis, Chaetoceros, S. tropicum and centric diatoms (10 to $30 \mu \mathrm{m}$ diameter).

The community in the sediment surface also differed from the surface and bottom water column (with picocyanobacteria omitted) because of the presence of filamentous cyanobacteria (Fig. 3), whose densities were sometimes greater than those of diatoms (e.g. C4 July 2008, C6B November 2006). The presence of filamentous cyanobacteria was common at Stns C4 and C6B, but not at Stn C8. March 2007 and June 2008 were the only 2 sample dates for which filamentous cyanobacteria were present at Stn C8. Other cyanobacteria, such as Merismopedia spp. and Anabaena spp., made up the cyanobacterial community at Stn C8 during summer 2006.

The respective niche (pelagic, tychopelagic, or benthic) of the autotrophic cells (no picocyanobacteria) in the sediment surface community was dominated by benthic types (Fig. 4). At all stations, a general seasonal sediment pattern was evident that included a higher percentage of benthos in the summer and a larger proportion of pelagic or tychopelagic cells in the fall and winter. The surface water and bottom water communities were dominated by pelagic phytoplankton. Abundant benthic types $\left(7 \times 10^{4}\right.$ to $1.8 \times 10^{5}$ cells $g$ dry sed $\left.{ }^{-1}\right)$ were found in the bottom water at Stn C6B in July 2007 and at Stn C8 in August 2006; few to no benthic cells were found in the surface water at any station.

\section{Environmental parameters}

The mean sediment composition varied among the stations ( $\mathrm{n}=42$ for each station). Stns $\mathrm{C} 4$ and C6B were the muddiest (\% mud: mean $\pm \mathrm{SE}_{\text {; }} \mathrm{Stn} \mathrm{C} 4=$ $90.5 \pm 1.3 \%$, Stn C6B $=92.4 \pm 0.11 \%$ ) and Stn C8 had the lowest mean mud content $(23.6 \% \pm 4.3)$. Stn $\mathrm{C} 4$ was less muddy in summer 2006 and winter and spring 2008, Stn C6B varied little, and Stn C8 was the most variable with 1 month (July 2006) being muddy. The muddier stations had higher mean sediment TOC (Stn C4 $=1.29 \%$, Stn C6B $=2.00 \%$ ) compared to Stn C8 $(0.59 \%)$, which varied the most in organic content consistent with the differing percentage of mud. The \% surface PAR reaching the seafloor was less than 1\% for all stations except Stn C4 in August 2006 (Fig. 5). The highest \% surface PAR values were obtained during the spring and summer at all stations. The PAR ( $\mu$ mol photons $\mathrm{m}^{-2} \mathrm{~s}^{-1}$ ) range for each station was: $\operatorname{Stn} C 4=0$ to $83(n=12), \operatorname{Stn} C 6 B=0$ to $10(n=13)$ and Stn $C 8=0.1$ to $22(n=10)$. The range of attenuation coefficients for each station was: Stn $\mathrm{C} 4=0.25$ to 0.68 , $\mathrm{Stn} \mathrm{C} 6 \mathrm{~B}=0.25$ to 0.63 , and $\mathrm{Stn} \mathrm{C} 8=$ 0.21 to 0.38 with a total mean for all stations of 0.40 $(\mathrm{n}=35)$. The bottom water environmental parameters followed a typical seasonal pattern (Fig. 6) with the concentration of dissolved oxygen $\left(\mathrm{mg} \mathrm{l}^{-1}\right)$ at all 3 stations being lower in the summer and higher in the winter; bottom water temperatures also followed a typical seasonal cycle. Summer hypoxia was more frequent at Stns C4 and C6B than C8. The salinity at Stn $\mathrm{C} 4$ varied the most and variation lessened with increasing depths (Stns C6B and C8). The $\mathrm{pH}$ of the bottom water was lower in the spring and summer months ( $~ 7.7$ for all stations) and increased in the fall and winter to $\sim 8$ (data not illustrated).

We constructed a PCA biplot (Fig. 7) with vectors representing abiotic and biotic variables to determine which variables were correlated. The station samples (C4, C6B and C8) were spread among the variables to which they were related, and the station samples that contained higher values were found closer to that variable label. According to the PCA biplot (Fig. 7), the PAR and bottom water temperature had the highest correlation (i.e. small angles between vectors) with the sediment biotic variables. Of all the nutrients analyzed, silicate had the highest correlation (smallest angle between vectors) with the sediment biotic variables. The sediment characteristics (\% sand and \% TOC) were not correlated with the sediment biotic variables (i.e. perpendicular vectors) and sediment TOC was inversely related to \% sand and depth (i.e. opposite vectors). In general, 

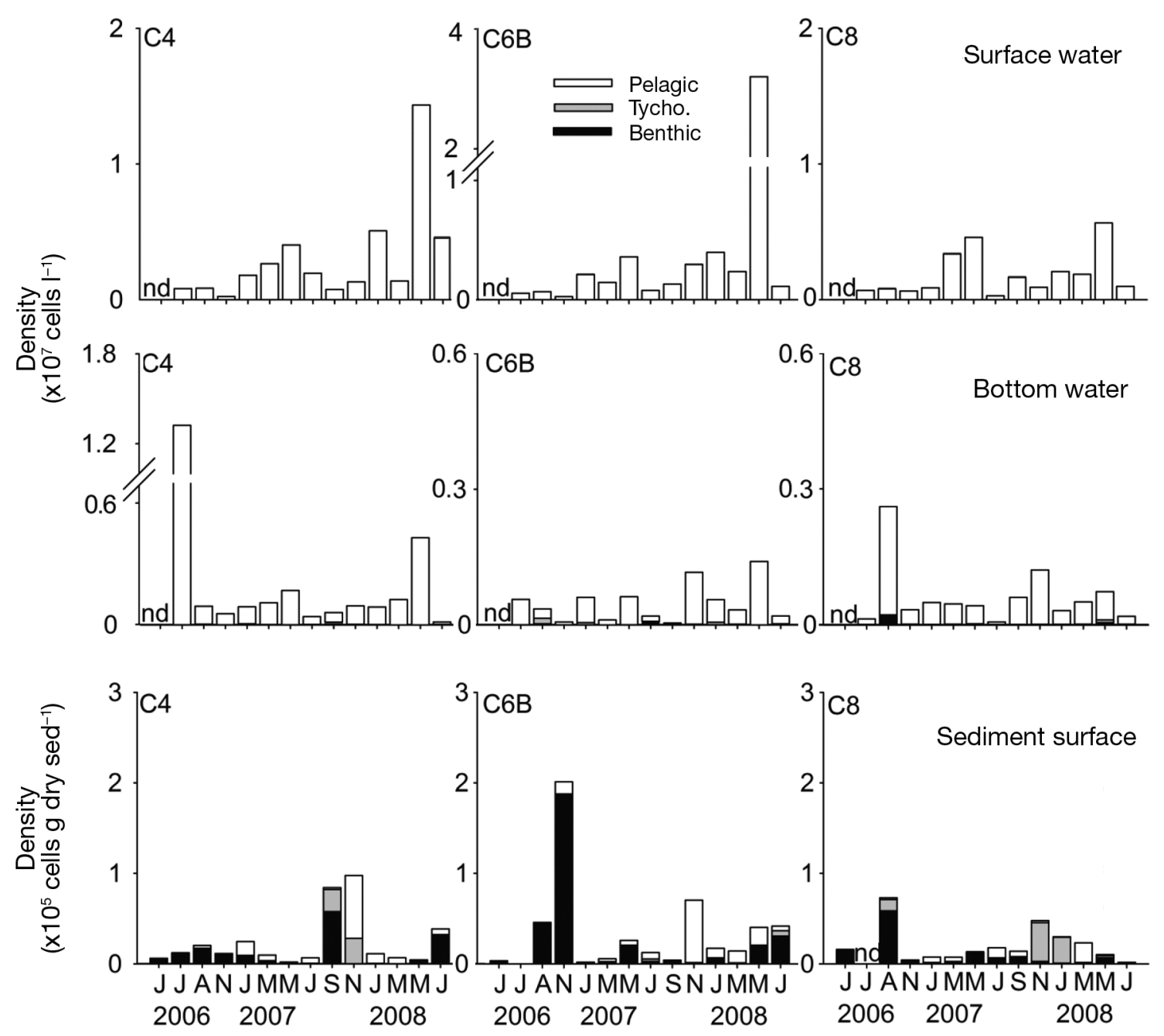

Fig. 4. Density of phytoplankton and microphytobenthos (no picocyanobacteria) by common niches (pelagic, tychopelagic or benthic) in the surface water, bottom water and sediment surface at Stns C4, C6B and C8 (see Fig. 1) from June 2006 to July 2008. $\mathrm{nd}=$ no data. Month abbreviations as in Fig. 2. Note the different $y$-axis ranges

Stns C6B and C4 were more closely related with each other than either was with C8 among the variables measured.

\section{DISCUSSION}

Our study covered a broader spatial area, more representative sedimentary characteristics, and seasonal and inter-annual variability among microphytobenthos than any study to date within the hypoxic area in the northern Gulf of Mexico (Grippo et al. 2009, 2010). Grippo et al.'s studies were confined mostly to sandy nearshore shoal areas with some surrounding muddy areas in regions that were intermittently hypoxic due to their higher bathymetric relief. Their samples were also temporally limited. Our stations were in areas that were frequently hypoxic (Fig. 1), and at similar depths to other areas on the shelf that are also hypoxic. The \% mud in sediments along an $18 \mathrm{~m}$ isobath at 11 stations from the Mississippi River to the Texas/Louisiana border ranges from 25 to $99 \%$, but is more commonly $>75 \%$, and has a \% TOC content ranging from 0.5 to $2.0 \%$, and averaging about $1.5 \%$ (authors' unpubl. data). The stations we sampled ranged from 24 to $92 \%$ mud and 0.6 to $2.0 \%$ TOC, which is characteristic of the larger region where hypoxia forms.

We hypothesized that the sediment surface microalgal community would be similar to the surface and bottom water as a result of high primary productivity in the surface waters and the subsequent settling of phytoplankton that fuels hypoxia, but we reject this hypothesis. Instead, microphytobenthos were com- 


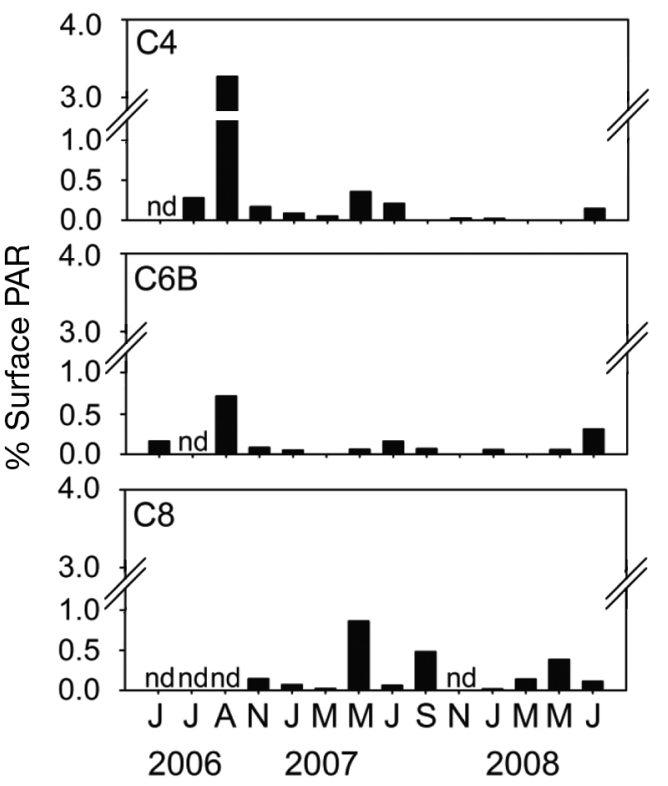

Fig. 5. Percent of surface photosynthetically available radiation (PAR) reaching the seafloor from June 2006 to July 2008 at Stns C4, C6B and C8 (see Fig. 1). nd = no data due to darkness at sampling. Month abbreviations as in Fig. 2

mon on the sediment surface, especially in the summer along the $\mathrm{C}$ transect. Although we did not measure benthic oxygen production in this study, we suspect that the suggestion of Dortch et al. (1994) that benthic photosynthesis could potentially contribute to oxygen dynamics is possible, based on the presence of microphytobenthos and the potentially significant irradiance values. We estimated that the net oxygen produced (based on Gattuso et al. 2006) at the highest irradiance $\left(80 \mu \mathrm{mol}\right.$ photons $\left.\mathrm{m}^{-2} \mathrm{~s}^{-1}\right)$ for $8 \mathrm{~h}$ of daylight and a $1 \mathrm{~m}$ deep water column would be about $1.5 \mathrm{mg} \mathrm{O}_{2} \mathrm{l}^{-1} \mathrm{~d}^{-1}$. This could influence oxygen dynamics when the sediment oxygen demand is low. For example, if oxygen consumption is at the low end of bottom water respiration rates $(0.02$ to $6.96 \mathrm{mg}$ $\mathrm{O}_{2} \mathrm{l}^{-1} \mathrm{~d}^{-1}$ ) (Rabalais et al. 1994, Turner et al. 1998) and sediment respiration rates $\left(0.2\right.$ to $4.6 \mathrm{mg} \mathrm{O}_{2} \mathrm{l}^{-1}$ $\mathrm{d}^{-1}$ ) (authors' unpubl. data), then the amount of oxygen produced could exceed bottom respiration, thus affecting hypoxia formation.

The dominant microphytobenthos ( $>3 \mu \mathrm{m}$ ) on the sediment surface were benthic diatoms and filamentous cyanobacteria that were different from the water-column phytoplankton. Even though the time scales may affect differences in community composition between water and sediment due to the varying settling rates of phytoplankton cells, fecal pellets and aggregates, the community composition difference

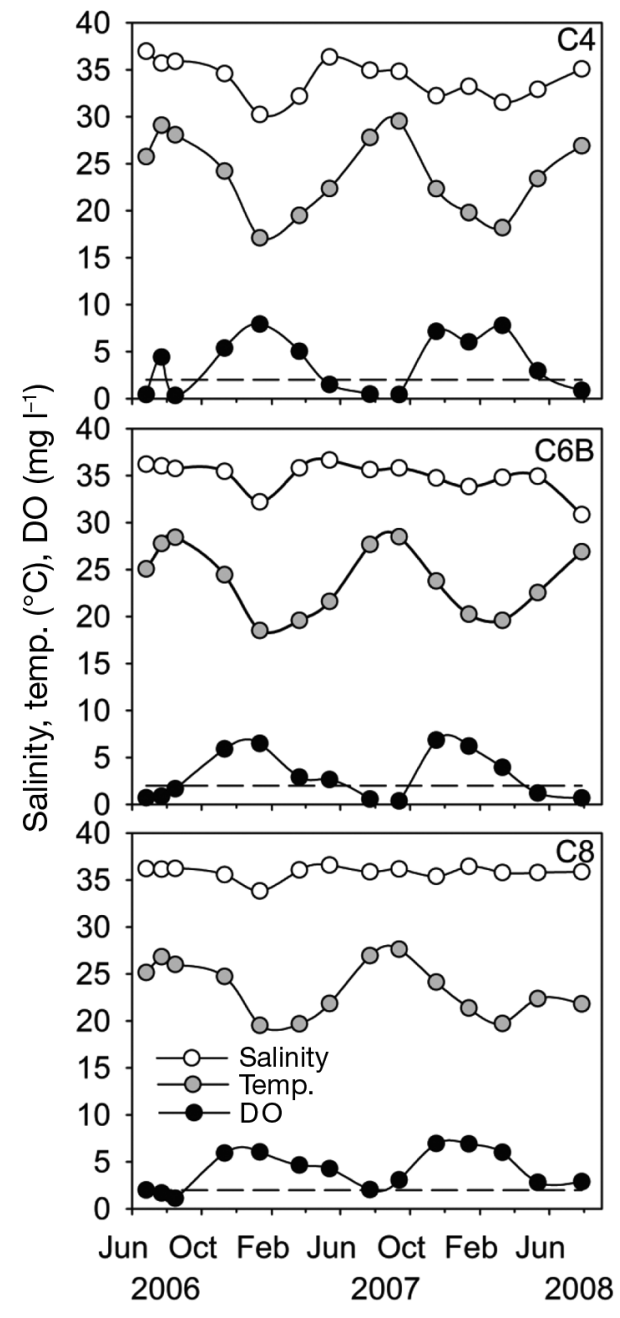

Fig. 6. Seasonal variation of bottom water salinity, temperature $\left({ }^{\circ} \mathrm{C}\right)$ and dissolved oxygen (DO, $\mathrm{mg} \mathrm{l}^{-1}$ ) at Stns C4, C6B and C8 (see Fig. 1) from June 2006 to July 2008. The dashed line at $2 \mathrm{mg} \mathrm{l}^{-1}$ is a reference for hypoxic conditions

was dominated by the presence of benthic cells. Much of the settled phytoplankton is packaged in fecal pellets (which can sink through a $20 \mathrm{~m}$ water column in $1 \mathrm{~d}$ ) and others are senescent diatoms (Dortch et al. 2001). The sinking rate of the senescent diatom cells is dependent on their size and their silica content (Dortch et al. 2001). Other pelagic phytoplankton, such as dinoflagellates, are either not grazed or are remineralized in the upper water column, because the concentration of peridinin in surface waters is not reflected in bottom waters or sediments. A similar situation is likely for cryptomonads, commonly part of the phytoplankton community off the central coast of Louisiana (Dortch et al. 2001). While the cells collected in the monthly samples from the surface waters are possibly not exactly represen- 


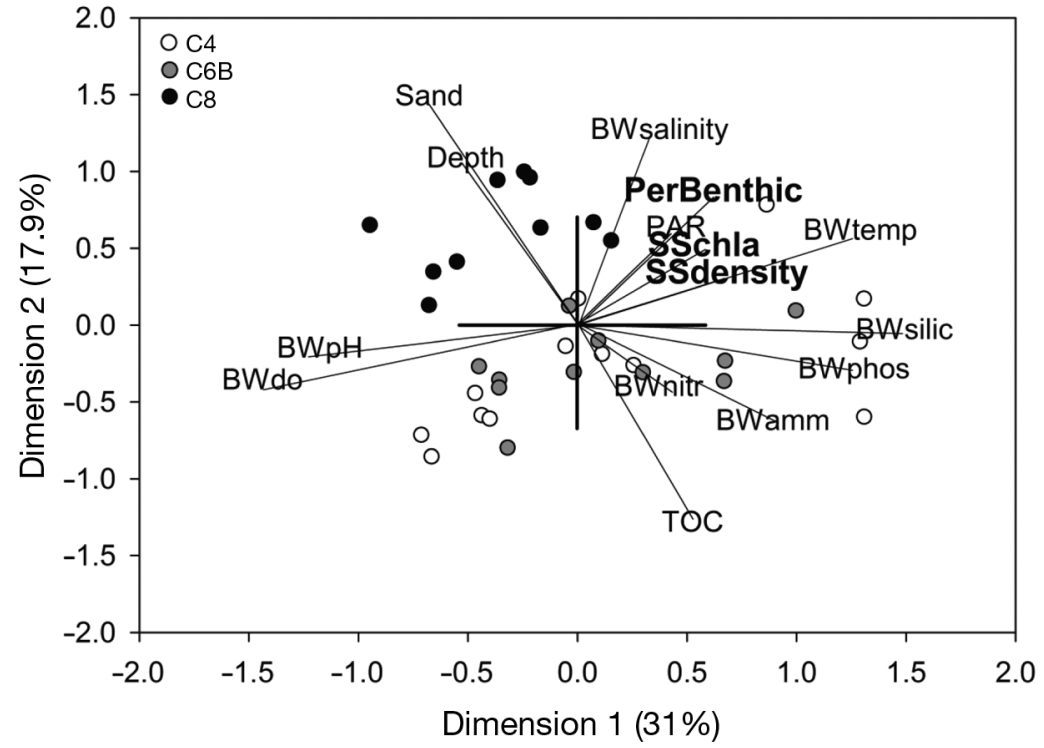

Fig. 7. Principal component analysis (PCA) biplot of sediment and bottom water (BW) abiotic variables and sediment biotic (bold) variables as vectors $(n=15)$ and station samples as points $(n=34)$. The abiotic variables included sediment percent sand, depth, bottom water salinity, seafloor photosynthetically available radiation (PAR), bottom water temperature, bottom water dissolved inorganic nutrients (silicate, phosphorus, ammonium and nitrate-nitrite), sediment percent total organic carbon (TOC), bottom water $\mathrm{pH}$ and dissolved oxygen (do). The sediment biotic variables included percent benthic cells (PerBenthic), sediment surface chlorophyll a (SSchla) and sediment surface benthic cell density (SSdensity). Perpendicular vectors are uncorrelated, vectors with small angles between them are highly correlated and opposite vectors are negatively correlated. Longer lengths of vectors indicate higher variability. Samples were removed from analysis if the data set was incomplete, mostly due to no PAR data. These included June 2006 (C4, C6B, C8), July 2006 (C6B, C8), August 2006 (C6B, C8) and November 2007 (C8)

tative of the cells in the bottom waters or in the sediment surface collected at the same time, a correlation among these communities is more likely than a 2 mo lag between surface communities and those of the lower water column and sediment surface (Qureshi 1995, Dortch et al. 2001).

The microphytobenthos are a common component of sub-tidal benthic systems, including areas of hypoxia, e.g. the northern Adriatic Sea (Totti 2003, Cibic et al. 2007), the Kattegat (Graneli \& Sundbäck 1986), and the northern Gulf of Mexico (Grippo et al. 2009, 2010, present study). Grippo et al. (2009, 2010) reported a higher percentage of benthic diatoms (based on pennate versus centric ratios) on the sediment surface. They also found a higher percentage of microphytobenthos on shallow (<11 m), sandy shoals compared to off-shoal muddier areas at their non-hypoxic sites west of our study area (50 to $150 \mathrm{~km}$ ). They did not document the concentration of filamentous cyanobacteria, which we found to be abundant, pos- sibly because of their adaptation to fluctuating environmental variables such as oxygen and $\mathrm{pH}$ (Shilo \& Fattom 1984). Larson \& Sundbäck (2008) have shown that benthic diatoms can survive hypoxic conditions in laboratory settings and assist in restoring sediment oxygen levels.

Microphytobenthos are known to persist and photosynthesize in light levels as low as $0.1 \%$ of the surface light and their photosynthetic response to increasing light levels can be rapid (Graneli \& Sundbäck 1986, Paterson 2001, Gerbersdorf et al. 2004, McGee et al. 2008). The seafloor light levels were low at all of our sites; the combined station average PAR was $5 \mu \mathrm{mol}$ photons $\mathrm{m}^{-2} \mathrm{~s}^{-1}$, or about $0.2 \%$ of the surface (reference) PAR $(\mathrm{n}=$ 36). The \% surface PAR levels reaching the seafloor observed in the study of Lehrter et al. (2009) were higher, ranging between 2 and $6 \%$ (for areas with $>1 \%$ light at the seafloor). We suggest that the limited light measurements we obtained probably did not fully capture the variability in light at each station. To our knowledge, no continuous light data have been reported for the inner continental shelf of the northern Gulf of Mexico, and this type of data would help improve our understanding of the potential for photosynthesis in the bottom water and on the seafloor. Nevertheless, the light data we do have suggest that light reaches the seafloor, especially in the summer. The results of the PCA biplot analysis (see Fig. 7) revealed a positive correlation between PAR at the seafloor and the percent benthic cells, chl a concentration, and benthic cell density, thus suggesting that light levels influence the presence and density of the microphytobenthic community. In addition, the spectral light quality can also affect the taxonomy of the community (Ploug et al. 1993, Cahoon 1999), and the rates of photosynthesis and oxygen evolution may be affected by these low light levels (MacIntyre et al. 1996).

Picocyanobacteria, containing either phycocyanin or phycoerythrin, were present in surface sediments at all stations. Cyanophytes with phycobillins are efficient at gathering low light (Brock 1973), which may be why they are present in the turbid, low-light environment of the northern Gulf of Mexico. Due to their small cell size, they make up a small fraction of 
the phytoplankton biomass ( $\mathrm{chl}$ a) (Dortch et al. 2001). Some of the community composition similarity among the sample types (SW, BW, SS) was due to the density of picocyanobacteria cells, which was documented as an increase in dissimilarity values with the removal of picocyanobacteria. Their presence in the sediment surface is probably due to direct sinking via diatom and/or picocyanobacteria aggregates (Dortch et al. 2001) because summer peaks were found in all sample types (SW, BW, SS). Also, the high abundance of PE picocyanobacteria at the 3 and $8 \mu \mathrm{m}$ filter size of the sediment samples indicates that these cells were part of aggregates. They were not abundant on the smaller filter size $(0.2 \mu \mathrm{m})$ which would indicate a flux of individual cells. Dortch (1998) also found that a high percentage (up to $60 \%$ ) of the picocyanobacteria (mostly PE) in water samples were captured on the large filter sizes $(3$ and $8 \mu \mathrm{m})$ and proposed that they were part of cell aggregates. Most benthic studies do not evaluate the smaller autotrophs $(<3.0 \mu \mathrm{m})$ and may, therefore, be missing a portion of the community, at least in abundance values.

Microscopy is clearly useful for estimating the cell density of different types of microphytobenthos and their niches. Additionally, identification of phytopigments helps to indicate and estimate the potential biomass of taxonomic groups of microphytobenthos. For example, the major carotenoid present in the sediment at all stations was fucoxanthin, which is a primary indicator pigment for diatoms, but prymnesiophytes, raphidophytes and some dinoflagellates with endosymbionts also contain fucoxanthin (Jeffrey et al. 1997). Our microscopic analysis verified high diatom densities, but these densities were not high in the summer, unlike the high summer fucoxanthin concentrations. This inconsistency could be due to the size of the diatoms and the pigment content per cell or the slower degradation of fucoxanthin in anoxic conditions (Hodgson et al. 1997). Lastly, it is important to note that the sediment pigment pools are influenced by sources of live, senescent and dead cells (phytoplankton and microphytobenthos), fecal pellets, aggregates, and environmental conditions (e.g. oxygen, temperature, PAR) (Sun et al. 1993, Hodgson et al. 1997, Hansen \& Josefson 2001). This makes it difficult to distinguish the source, but microscopy helps estimate the potential living contribution.

The range in mean sediment chl a values ( 0.36 to $0.99 \mu \mathrm{g} \mathrm{g}$ dry $\mathrm{sed}^{-1}$ ) was similar to those of other studies that had microphytobenthos present; caution, however, is advised when comparing results ob- tained with a different methodology (spectrophotometry vs. HPLC). In Onslow Bay, North Carolina, for example, the mean sediment chl a value, based on spectrophotometric methods, at 20 to $29 \mathrm{~m}$ depth was $0.67 \mu \mathrm{g} \mathrm{g}$ dry $\operatorname{sed}^{-1}$ (Cahoon et al. 1990), and in coastal Massachusetts it ranged between 0 and $2.5 \mu \mathrm{g} \mathrm{g} \mathrm{dry} \mathrm{sed}{ }^{-1}$ (Cahoon et al. 1999). We found the concentration of chl a in sediments was usually less than the total carotenoid pigment concentration (especially fucoxanthin). McGee et al. (2008) suggested that benthic diatoms may adapt to low light levels by producing fucoxanthin concentrations resulting in high fucoxanthin:chl a ratios. They found that this ratio in Onslow Bay, North Carolina increased from $\sim 2: 1$ to $5: 1$ in shallow sites $(<35 \mathrm{~m}, 81 \mu \mathrm{mol}$ photons $\left.\mathrm{m}^{-2} \mathrm{~s}^{-1}\right)$ compared to deeper, lower light sites $(63 \mathrm{~m}$ and $2.34 \mu \mathrm{mol}$ photons $\mathrm{m}^{-2} \mathrm{~s}^{-1}$ ). The fucoxanthin:chl $a$ ratios $(\mathrm{n}=5)$ for samples with $>75 \%$ benthic cells were 2.4:1 (Stn C4), 3.5:1 (Stn C6B) and 1.4:1 (Stn $\mathrm{C} 8$ ), which are comparable to the 2:1 ratio value of the shallow sites in the study of McGee et al. (2008). Microphytobenthos on the Louisiana continental shelf may be producing higher concentrations of fucoxanthin than chl $a$ to adapt to the low light levels on the seafloor.

Stn C8 had the highest sediment chl a level $\left(0.99 \mu \mathrm{g} \mathrm{g} \mathrm{dry} \mathrm{sed}{ }^{-1}\right)$, which is supportive of our prediction for a well-developed microphytobenthos community there. The lowest frequency of hypoxia occurred there along with overall less frequent midsummer hypoxia ( 25 to $50 \%$ ) in the past $23 \mathrm{yr}$ than at Stns $\mathrm{C} 4$ and $\mathrm{C} 6 \mathrm{~B}$, which experienced hypoxia $>75 \%$ of the time. We predicted that the microphytobenthos at Stn C8 were less likely to be light limited due to less phytoplankton shading, but all stations had similar chl a levels in the surface water during our study. Stns C4 and C6B had finer sediments that might be more susceptible to physical resuspension by wave activity, bottom currents and shrimp trawling, thus affecting the light levels reaching the bottom. However, the sediment characteristics (\% sand or $\%$ TOC) at the 3 stations were not correlated with the presence of microphytobenthos (see Fig. 7). The variables that correlated with the presence of microphytobenthos were the seafloor PAR, bottom water temperature and salinity. This suggests that microphytobenthos are more likely to be present when higher levels of seafloor PAR, warmer temperatures and higher salinity exist, i.e. during summer when hypoxia occurs.

The presence of the benthic cells, primarily pennate diatoms, during summer hypoxia may also be enhanced by hypoxia-related conditions. High nutri- 
ent fluxes from remineralized organic matter (Rabalais \& Turner 2006, Rabalais et al. 2007a, authors' unpubl. data) in the sediments could support diatom communities where light is sufficient. The silicate concentrations in bottom water doubled, reaching 40 to $80 \mu \mathrm{M}$ when oxygen levels fell from 2 to $1 \mathrm{mg} \mathrm{l}^{-1}$ (Rabalais \& Turner 2006). Thus, the silicate necessary for diatom frustule formation was more available during extremely low oxygen conditions (0 to $1 \mathrm{mg}^{-1}$ ), than in non-hypoxic conditions, and could support a community of benthic diatoms (e.g. Sigmon \& Cahoon 1997). In addition, hydrogen sulfide toxicity and the mortality of benthic infauna occur in hypoxic conditions (Baustian \& Rabalais 2009 and references therein). A reduction in grazing pressure by macroinfauna (Miller et al. 1996, Middelburg et al. 2000) could result in higher densities of microphytobenthos compared to areas with a functioning macroinfaunal community in normoxic bottom water. The digestive tracts of some surface deposit-feeding polychaetes from one of these stations contained pennate diatoms (M. M. Baustian unpubl. data), as did those from nearby sites (Grippo et al. 2011), and the density of these polychaetes decreases with hypoxia (Baustian \& Rabalais 2009). Alternatively, with excess primary production from the water column, the benthic grazing pressure on microphytobenthos may be reduced (Grippo et al. 2011). Suitable conditions for growth of benthic diatoms coupled with decreased grazing pressure would support a healthy microphytobenthic community, and especially larger pennate forms.

Another reason why microphytobenthos might be present on the hypoxic continental shelf is the release of organic molecules from the sediment during mineralization of phytodetritus. This organic substrate could provide benthic diatoms with an alternative nutritional mode via heterotrophy or mixotrophy when environmental conditions, such as light, are not favorable (Round et al. 1990, Cahoon et al. 1994).

Our observations indicate that microphytobenthos are present on the sediment surface throughout the year, but more so in the summer, and that the benthic community differs from the water column phytoplankton community in the northern Gulf of Mexico. As a result of their presence, we propose that microphytobenthos present during the summer in our study area and elsewhere in similar depths where hypoxia occurs may produce enough oxygen to significantly influence the bottom water oxygen budget. Measurements of the oxygen fluxes under light and dark conditions would be useful for quantifying the net yield of oxygen from the benthic community.
Acknowledgements. We thank the members of the Rabalais Laboratory (N. Atilla, J. Lasseigne, L. Pride, D. Richardi, E. Robinson, A. Sapp and T. Widgeon), Turner Laboratory (J. Lee and C. Milan) and the RV 'Pelican' captain and crew for helping collect water and sediment samples. Special thanks to C. Milan, D. Richardi and T. Widgeon for their assistance with the laboratory analyses. We acknowledge T. Widgeon for the map in Fig. 1, E. Swenson for organizing the light data and $M$. Sullivan for benthic diatom identification advice. Funding was provided by the National Oceanic and Atmospheric Administration (NOAA) Center for Sponsored Coastal Ocean Research grant no. NA06NPS4780197 to N.N.R. (LUMCON) and no. NA16OP2670 to R.E.T. (LSU). This is NOAA CSCOR NGOMEX publication number 137.

\section{LITERATURE CITED}

Baustian MM, Rabalais NN (2009) Seasonal composition of benthic macroinfauna exposed to hypoxia in the northern Gulf of Mexico. Estuaries Coasts 32:975-983

Blanchard G, Chretiennot-Dinet MJ, Dinet A, Robert JM (1988) A simplified method for sorting microphytobenthos from marine sediment using a Ludox silica-sol. CR Acad Sci Série III 307:569-576

Brock TD (1973) Evolutionary and ecological aspects of cyanophytes. In: Carr NG, Whitton BA (eds) The biology of blue-green algae. University of California Press, Berkeley, p 487-500

Cahoon LB (1999) The role of benthic microalgae in neritic ecosystems. Oceanogr Mar Biol Annu Rev 37:47-86

Cahoon LB, Redman RS, Tronzo CR (1990) Benthic microalgal biomass in sediments of Onslow Bay, North Carolina. Estuar Coast Shelf Sci 31:805-816

Cahoon LB, Laws RA, Thomas CJ (1994) Viable diatoms and chlorophyll $a$ in continental slope sediments off Cape Hatteras, North Carolina. Deep-Sea Res II 41:767-782

> Cahoon LB, Nearhoof JE, Tilton CL (1999) Sediment grain size effect on benthic microalgal biomass in shallow aquatic ecosystems. Estuaries 22:735-741

Cibic T, Blasutto O, Falconi C, Umani SF (2007) Microphytobenthic biomass, species composition and nutrient availability in sublittoral sediments of the Gulf of Trieste (northern Adriatic Sea). Estuar Coast Shelf Sci 75:50-62

Dortch Q (1998) Phytoplankton characteristics. In: Murray SP (ed) An observational study of the MississippiAtchafalaya coastal plume: final report. OCS Study MMS 98-0040. US Dept of the Interior, Minerals Management Service, Gulf of Mexico OCS Region, New Orleans, LA, p 239-268

> Dortch Q, Rabalais NN, Turner RE, Rowe GT (1994) Respiration rates and hypoxia on the Louisiana shelf. Estuaries 17:862-872

Dortch Q, Rabalais NN, Turner RE, Qureshi NA (2001) Impacts of changing $\mathrm{Si} / \mathrm{N}$ ratios and phytoplankton species composition. In: Rabalais NN, Turner RE (eds) Coastal hypoxia: consequences for living resources and ecosystems. Coastal and Estuarine Studies 58, American Geophysical Union, Washington, DC, p 37-48

Fuller MF, Butman CA (1988) A simple technique for finescale, vertical sectioning of fresh sediment cores. J Sediment Petrol 58:763-768

Gattuso JP, Gentilli B, Duarte CM, Kleypas JA, Middelburg JJ, Antoine D (2006) Light availability in the coastal ocean: impact on the distribution of benthic photosyn- 
thetic organisms and their contribution to primary production. Biogeosciences 3:489-513

Gerbersdorf SU, Meyercordt J, Meyer-Reil LA (2004) Microphytobenthic primary production within the flocculent layer, its fractions and aggregates, studied in two shallow Baltic estuaries of different eutrophic status. J Exp Mar Biol Ecol 307:47-72

Graneli W, Sundbäck K (1986) Can microbenthic photosynthesis influence below-halocline oxygen conditions in the Kattegat? Ophelia 26:195-206

Grippo MA, Fleeger JW, Condrey R, Carmen KR (2009) High benthic microalgal biomass found on Ship Shoal, north-central Gulf of Mexico. Bull Mar Sci 84:237-256

Grippo MA, Fleeger JW, Rabalais NN, Condrey R, Carman KR (2010) Contribution of phytoplankton and benthic microalgae to inner shelf sediments of the north-central Gulf of Mexico. Cont Shelf Res 30:456-466

Grippo MA, Fleeger JW, Dubois SF, Condrey R (2011) Spatial variation in basal resources supporting benthic food webs revealed for the inner continental shelf. Limnol Oceanogr 56:841-856

Hansen JLS, Josefson AB (2001) Pools of chlorophyll and live planktonic diatoms in aphotic marine sediments. Mar Biol 139:289-299

> Hedges JI, Stern JH (1984) Carbon and nitrogen determinations of carbonate-containing solids. Limnol Oceanogr 29:657-663

> Hodgson DA, Wright SW, Davies N (1997) Mass spectrometry and reverse phase HPLC techniques for the identification of degraded fossil pigments in lake sediments and their application in paleolimnology. J Paleolimnol 18: 335-350

Jeffrey SW, Mantoura RFC, Bjørnland T (1997) Part IVData for the identification of 47 key phytoplankton pigments. In: Jeffrey SW, Mantoura RFC, Wright SW (eds) Phytoplankton pigments in oceanography: guidelines to modern methods. Monographs on oceanographic methodology, Vol 10. UNESCO Publishing, Paris, p 449-559

Komárek J, Kling HJ, Komárková J (2003) Filamentous cyanobacteria. In: Wehr JD, Sheath RG (eds) Freshwater algae of North America: ecology and classification. Academic Press, San Diego, CA, p 117-196

> Larson F, Sundbäck K (2008) Role of microphytobenthos in recovery of functions in a shallow-water sediment system after hypoxic events. Mar Ecol Prog Ser 357:1-16

> Lehrter JC, Murrell MC, Kurtz JC (2009) Interactions between freshwater input, light and phytoplankton dynamics on the Louisiana continental shelf. Cont Shelf Res 29: 1861-1872

Lohrenz SE, Dagg MJ, Whitledge TE (1990) Enhanced primary production at the plume/oceanic interface of the Mississippi River. Cont Shelf Res 10:639-664

> MacIntyre HL, Geider RJ, Miller DC (1996) Microphytobenthos: The ecological role of the 'secret garden' of unvegetated, shallow-water marine habitats. I. Distribution, abundance and primary production. Estuaries 19: 186-201

> McGee D, Laws RA, Cahoon LB (2008) Live benthic diatoms from the upper continental slope: extending the limits of marine primary production. Mar Ecol Prog Ser 356: 103-112

Middelburg JJ, Barranguet C, Boschker H, Herman PMJ, Moens T, Heip CHR (2000) The fate of intertidal microphytobenthos carbon: an in situ ${ }^{13} \mathrm{C}$-labeling study. Limnol Oceanogr 45:1224-1234
Miller DC, Geider RJ, MacIntyre HL (1996) Microphytobenthos: the ecological role of the 'secret garden' of unvegetated, shallow-water marine habitats. II. Role in sediment stability and shallow-water food webs. Estuaries 19: 202-212

Murrell MC, Lehrter JC (2011) Sediment and lower water column oxygen consumption in the seasonally hypoxic region of the Louisiana continental shelf. Estuaries Coasts 34:912-924

Paterson DM (2001) The fine structure and properties of the sediment surface. In: Boudreau BP, Jorgensen BB (eds) The benthic boundary layer, transport processes and biogeochemistry. Oxford University Press, Oxford, p 127-143

> Ploug H, Lassen C, Jorgensen BB (1993) Action spectra of microalgal photosynthesis and depth distribution of spectral scalar irradiance in a coastal marine sediment of Limfjorden, Denmark. FEMS Microbiol Ecol 12:69-78

Quiñones-Rivera ZJ, Wissel B, Rabalais NN, Justi D (2010) Effects of biological and physical factors on seasonal oxygen dynamics in a stratified, eutrophic coastal ecosystem. Limnol Oceanogr 55:289-304

Qureshi NA (1995) The role of fecal pellets in the flux of carbon to the sea floor on a river-influenced continental shelf subject to hypoxia. PhD dissertation, Louisiana State University, Baton Rouge, LA

Rabalais NN, Turner RE (2006) Oxygen depletion in the Gulf of Mexico adjacent to the Mississippi River. In: Neretin LN (ed) Past and present water column anoxia. Springer, Dordrecht, p 225-245

Rabalais NN, Wiseman WJ Jr., Turner RE (1994) Comparison of continuous records of near-bottom dissolved oxygen from the hypoxia zone along the Louisiana coast. Estuaries 17:850-861

Rabalais NN, Turner RE, Scavia D (2002) Beyond science into policy: Gulf of Mexico hypoxia and the Mississippi River. Bioscience 52:129-142

Rabalais NN, Turner RE, Sen Gupta BK, Boesch DF, Chapman P, Murrell MC (2007a) Characterization and longterm trends of hypoxia in the northern Gulf of Mexico: Does the science support the Action Plan? Estuaries Coasts 30:753-772

Rabalais NN, Turner RE, Sen Gupta BK, Platon E, Parsons M (2007b) Sediments tell the history of eutrophication and hypoxia in the northern Gulf of Mexico. Ecol Appl 17: S129-S143

Round FE, Crawford RM, Mann DG (1990) The diatoms: biology and morphology of the genera. Cambridge University Press, Cambridge

Shilo M, Fattom A (1984) The ecology and adaptive strategies of benthic cyanobacteria. In: Codd GA (ed) Aspects of microbial metabolism and ecology, Vol 11. Academic Press, Orlando, FL, p 175-186

Sigmon DE, Cahoon LB (1997) Comparative effects of benthic microalgae and phytoplankton on dissolved silica fluxes. Aquat Microb Ecol 13:275-284

Sklar FH, Turner RE (1981) Characteristics of phytoplankton production off Barataria Bay in an area influenced by the Mississippi River. Cont Shelf Res 24:93-106

> Sun M, Lee C, Aller RC (1993) Anoxic and oxic degradation of ${ }^{14} \mathrm{C}$-labeled chloropigments and a ${ }^{14} \mathrm{C}$-labeled diatom in Long Island Sound sediments. Limnol Oceanogr 38: 1438-1451

Tomas CR (1997) Identifying marine phytoplankton. Academic Press, San Diego, CA 
Totti C (2003) Influence of the plume of the river Po on the distribution of subtidal microphytobenthos in the northern Adriatic Sea. Bot Mar 46:161-178

Turner RE, Allen RL (1982) Plankton respiration rates in the bottom waters of the Mississippi River Delta bight. Contrib Mar Sci 25:173-179

Turner RE, Qureshi N, Rabalais NN, Dortch Q, Justi D, Shaw RF, Cope J (1998) Fluctuating silicate:nitrate ratios and coastal plankton food webs. Proc Natl Acad Sci USA

Editorial responsibility: Pei-Yuan Qian,

Kowloon, Hong Kong SAR
95:13048-13051

USEPA (US Environmental Protection Agency) (1983) Methods for chemical analysis of water and wastes. EPA600/4-79-020. USEPA, Cincinnati, $\mathrm{OH}$

Wright SW, Jeffrey SW, Mantoura RFC, Llewellyn CA, Bjornland T, Repeta D, Welschmeyer N (1991) Improved HPLC method for the analysis of chlorophylls and carotenoids from marine phytoplankton. Mar Ecol Prog Ser 77:183-196

Submitted: November 26, 2010; Accepted: June 15, 2011 Proofs received from author(s): August 22, 2011 